\title{
Deformite analizinde temel kavramlar ve değerlendirme
}

\author{
Basic rules on deformity analysis and evaluation
}

\author{
Murat Oto \\ Pamukkale Üniversitesi Tıp Fakültesi, Ortopedi ve Travmatoloji Anabilim Dalı, Denizli
}

Deformite kelimesi, normal anatomiden sapma anlamına gelmekte olup, tek planlı basit bir şekil bozukluğundan, üç boyutta komplike bir probleme kadar geniş bir yelpazeyi içerir. Sebeplerine baktığımızda; konjenital (doğumsal), kazanılmış, nörojenik ve travma sonrası oluşan nedenler karşımıza çıkmaktadır. Deformite analizi yaparken hem 'radyolojik' hem de 'klinik' değerlendirme yapılması şart olup, 'radyolojik' değerlendirme kendine ait kuralları ile yapılmaIı, güvenilir ve tekrarlanabilir olmalı; patellanın pozisyonu, hastanın film kasetine uzaklığı vb. detaylar atlanmamalıdır. Klinik değerlendirme ise hastanın detaylı fizik muayenesini içermeli, yürüme analizi mümkünse yapılmalı, deformitenin dinamik veya statik olduğuna karar verilmelidir. Özellikle rotasyonel problemlerde klinik muayenenin radyolojik değerlendirmeden daha kıymetli olabileceği unutulmamalıdır. Radyolojik ve klinik değerlendirme sonrasında deformiteyi analiz etmek, tedavi planı yapmak ve tedavi sonucunu değerlendirmek için öncelikle temel kavramların ve prensiplerin bilinmesi gerekmektedir. Yönelim, dizilim kelimelerinin anlamları, mekanik ve anatomik eksenlerin nasıl çizildiği, eklem oryantasyon çizgileri ile mekanik ve anatomik eksenler arası ilişkiler bilinmeli ve fizyolojik sınırları gösteren açılara hâkim olunmalıdır.

Anahtar sözcülkler: deformite; analiz; dizilim; yönelim
Deformity as a word addresses differentiating from normal anatomy. It includes a large spectrum of problems from one plane simple deformity to complex problems in 3 planes. Congenital, iatrogenic, neurological and posttraumatic causes are the mostly seen etiologic factors. Detailing deformity analysis needs evaluating patients in radiologic and clinical manners. Radiological evaluation has to be reliable and repeatable. There are some rules to obey like taking patella forward X-rays and putting the cassette to a proper distance. Clinical evaluation should include detailed physical exam, gait analysis if possible, and checking pattern of deformity to conclude whether the problem is dynamic or static. Particularly, in rotational problems surgeon should not forget that clinical exam is much more valuable than radiological evaluation. After radiologic and clinical evaluation, to analyze the deformity and to plan the treatment protocol, basic principles and concepts should be underlined. The meaning of orientation, alignment, how to draw mechanical and anatomic axes, and the relationship between joint orientation line and anatomic/mechanic axes and angles showing physiological borders should be known.

Key words: deformity; analysis; alignment; orientation

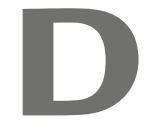
eformite; kelime olarak 'şekil bozukluğu' , 'normal anatomiden sapma' anlamına gelmekte olup, dört parametreden oluşmaktadır. ${ }^{[1]}$

1. Açısal deformiteler

2. Rotasyonel deformiteler

3. Translasyonel deformiteler

4. Kısalık

Deformiteler izole olarak tek bir parametre ile karşımıza çıkabileceği gibi, birden fazla parametreyi içeren kombine deformiteler olarak da karşımıza çıkabilir (Rotasyon-translasyon deformitesi, angulasyon-rotasyon deformitesi vb.).

Deformitelerin oluşum mekanizmalarına baktığımızda karşımıza;

\section{Doğumsal}

2. Kazanılmış

3. Nörojenik

4. Travma sonrası oluşan nedenler çıkmaktadır.

- İletişim adresi: Prof. Dr. Murat Oto, Pamukkale Üniversitesi Tıp Fakültesi, Ortopedi ve Travmatoloji Anabilim Dalı, Denizli Tel: 0532 - 4271343 e-posta: muratoto@hotmail.com

- Geliş tarihi: 6 Aralık 2019 Kabul tarihi: 13 Șubat 2020 


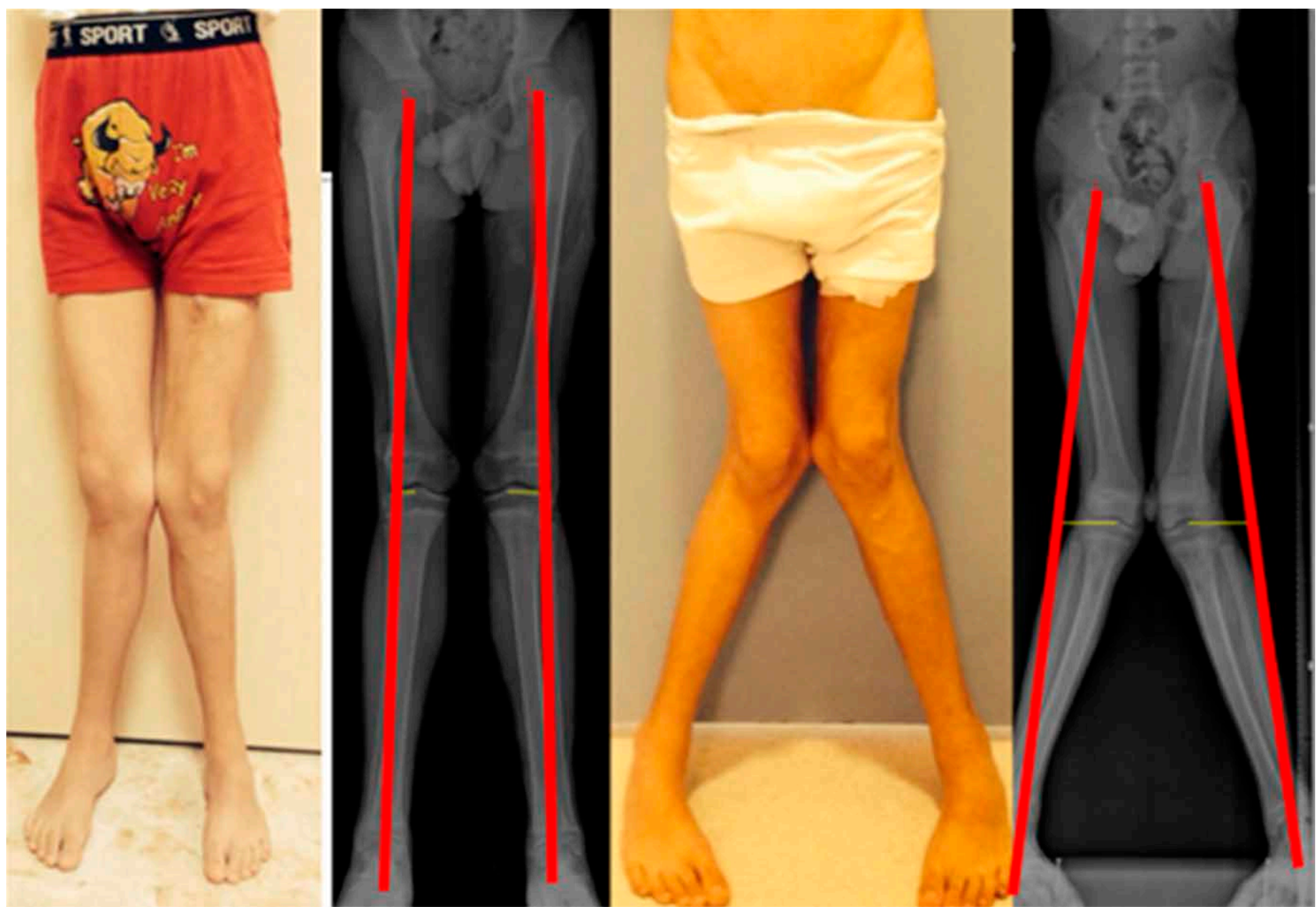

Şekil 1. Patellanın orta hatta olmasına film çekilirken dikkat edilmelidir.

Deformite analizi dendiğinde kastedilen, alt ekstremitede basit bir travmaya bağlı oluşmuş femur cisim kırığından, tibial hemimeli gibi komplike bir konjenital deformiteye kadar uzanan geniş yelpazedeki sorunları aynı prensiplere bağlı kalarak ortaya koymak, değerlendirmek ve tedavi etmektir.

Deformite analizi yapmak için hastalarımıza hem 'radyolojik' hem de 'klinik' değerlendirme yapılmalı; 'radyolojik' değerlendirme ön planda gibi gözükse de, klinik muayenenin önemi, özellikle rotasyonel deformitelerde yapılan fizik muayene ve yürüme analizinin kıymeti akılda tutulmalıdır.

Radyolojik tetkiklerin güvenilir ve tekrarlanabilir olması, standart görüntüler olması, bacak uzunluk grafisi çekilirken patella'nın orta hatta olması gerekliliği unutulmamalıdır. Şekil 1'de Hipofosfatemik Rickets hastalığı olan bir erkek hastanın patella yanda ve önde iken çekilen fotoğraf ve X-ray'leri arasındaki fark görülmektedir.
Radyolojk ve klinik değerlendirme sonrasında deformiteyi analiz etmek, tedavi planı yapmak ve tedavi sonrası sonucu değerlendirmek ilk önce temel kavramları ve prensipleri bilmek önemlidir. ${ }^{[2]}$

Problemin ne olduğunu ortaya koymak için öncelikle normal dizilim (alignment) ve yönelim (orientation)'in ne olduğu bilinmelidir. ${ }^{[3]}$

Alignment (dizilim): Kalça, diz ve ayak bileği eklemlerinin uzunlamasına yerleşiminin fizyolojik konumda olması anlamına gelirken (Şekil 2a),

Oryantasyon (yönelim): Bir uzun kemiğin (femur veya tibia) eklem yüzeyinin aynı kemiğin anatomik veya mekanik eksenine göre fizyolojik konumuna denir. Her eklemin bir 'eklem oryantasyon çizgisi' vardır. Frontal (Şekil 2b) ve sagittal planda (Şekil 2c) açılar ile birlikte şematize edilmiştir.

Malalignment (Dizilim bozukluğu): Kalça diz ve ayak bileği eklemlerinin uzunlama yerleşiminin fizyolojik 


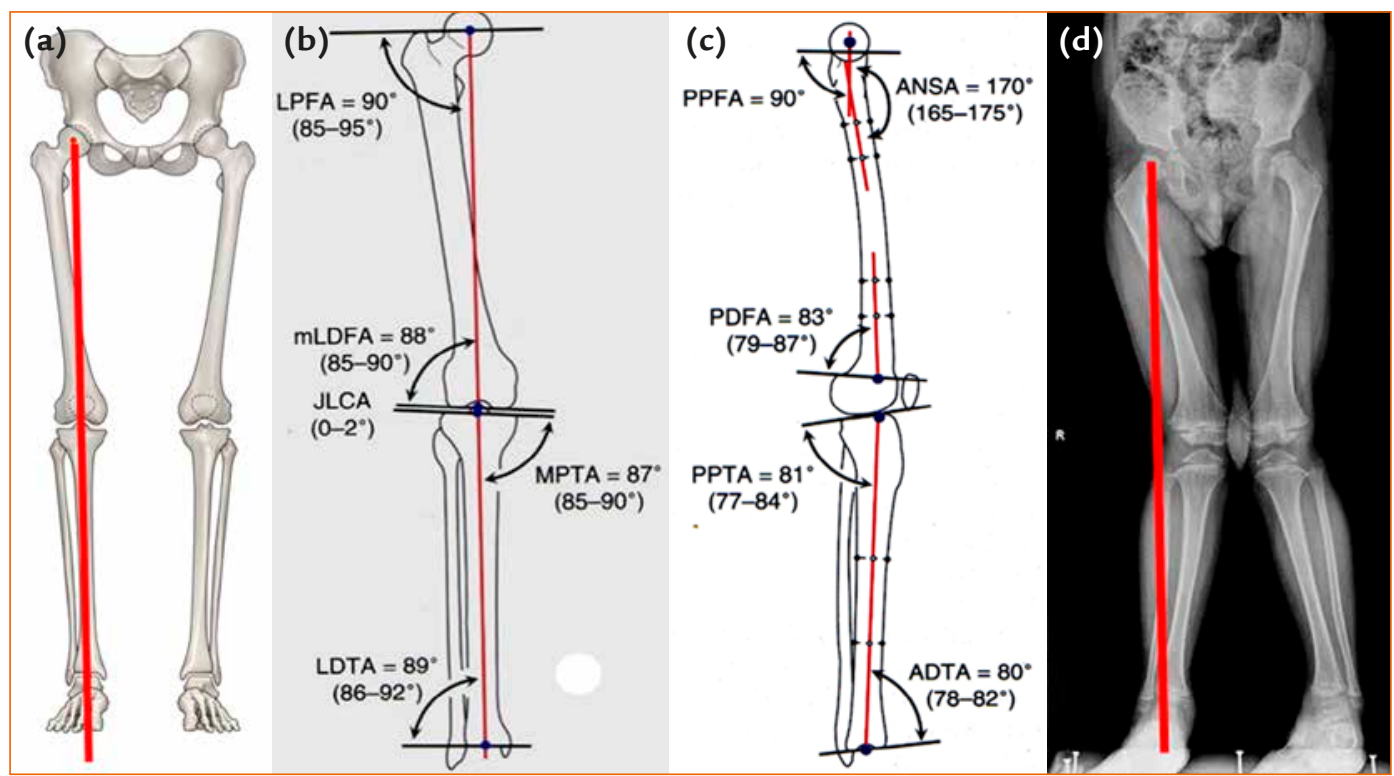

Şekil 2. a-d. Alt ekstremite mekanik aksı (a). Frontal planda eklem oryantasyon çizgileri ve mekanik aks birleşiminde ortaya çıkan açılar (b). Sagittal planda eklem oryantasyon çizgileri ve anatomik aks birleşiminde ortaya çıkan açılar (c). Multipl epifizyel displazisi olan bir hastada dizilim bozukluğu (malalignment) (d).

(a)

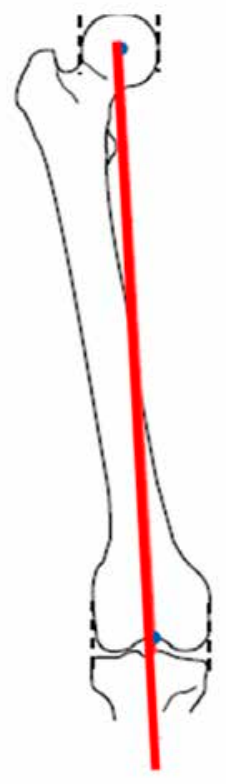

(b)

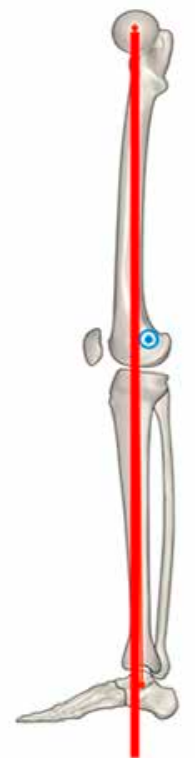

(c)

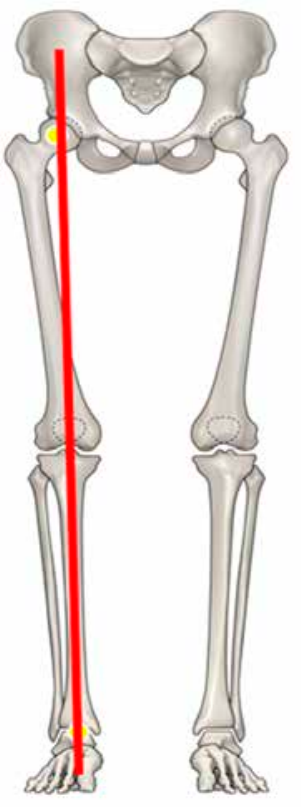

(d)

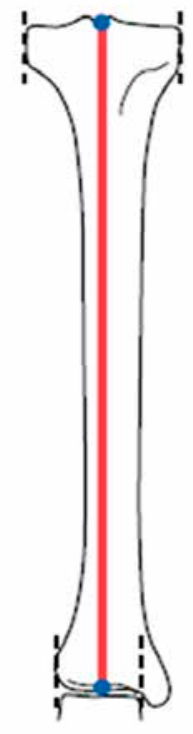

Şekil 3. a-d. Femurun frontal planda anatomik aksı (a). Sagittal planda alt ekstremitenin mekanik aksı (b). Frontal planda alt ekstremitenin mekanik aksı (c). Tibianın frontal planda mekanik aksı (d).

konumda olmamasına denir. Şekil 2d'de kalça-dizayak bileği diziliminin bozulduğu bir multipl epifizyal displazi hastasını görüyoruz.

Maloryantasyon (Kötü yönelim): Bir uzun kemiğin eklem yüzeyinin aynı kemiğin anatomik veya mekanik eksenine göre fizyolojik konumunun bozulmasına denir.
Her uzun kemiğin anatomik ve mekanik eksen olmak üzere iki ekseni vardır. Deformite analizinden önce bu eksenleri ve bazı terimleri tanımlamak gerekir. ${ }^{[1]}$

Mekanik eksen (aks): Bir uzun kemiğin proksimal ve distal eklemlerinin merkezi noktalarını birleştiren düz çizgi olarak tanımlanır. Frontal (Şekil 3a) ve sagittal planda (Şekil 3b), femurda (Şekil 3c) ve tibiada (Şekil 3d) 


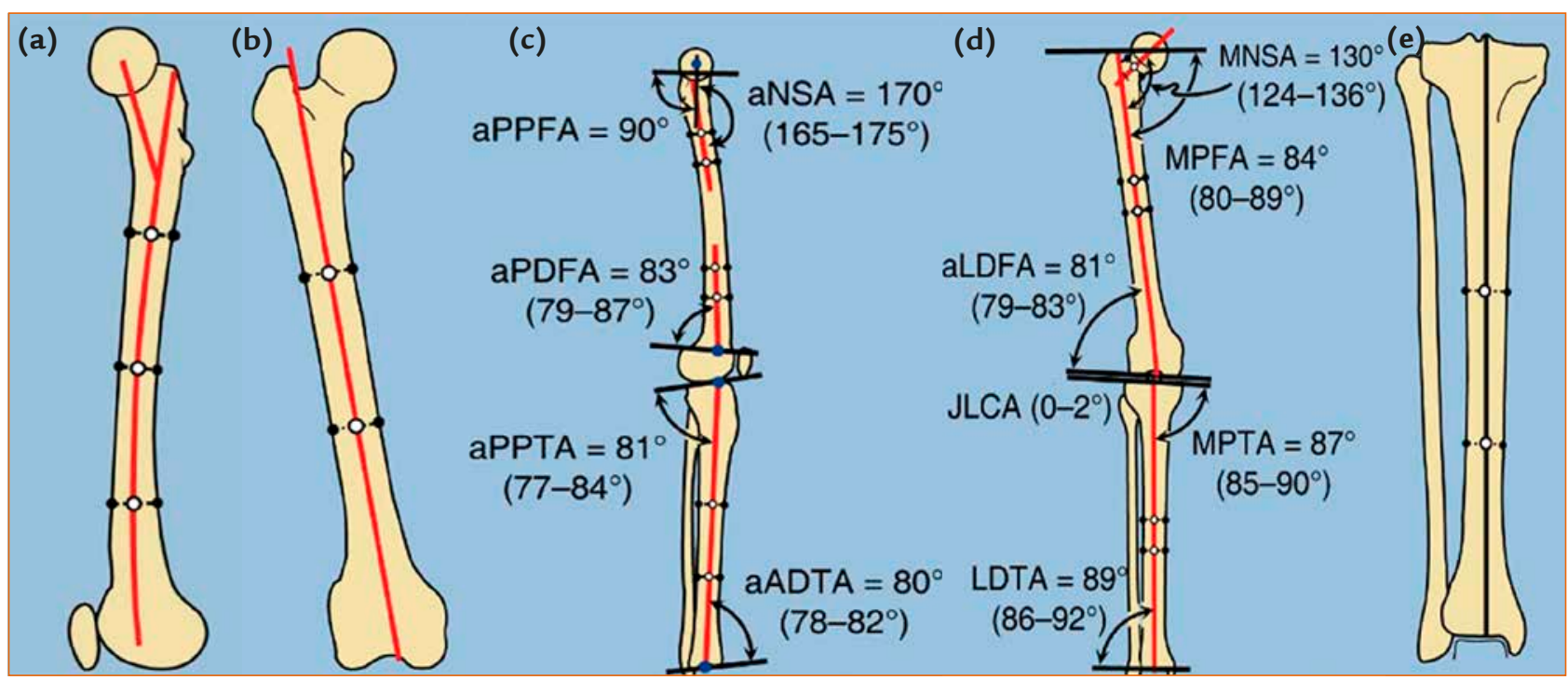

Şekil 4. a-e. Femurun sagittal planda anatomik aksı (a). Femurun frontal planda anatomik aksı (b). Alt ekstremitenin sagittal planda anatomik aksı ve açılar (c). Alt ekstremitenin frontal planda anatomik aksı ve açılar (d). Tibianın frontal planda anatomik aksı (e).

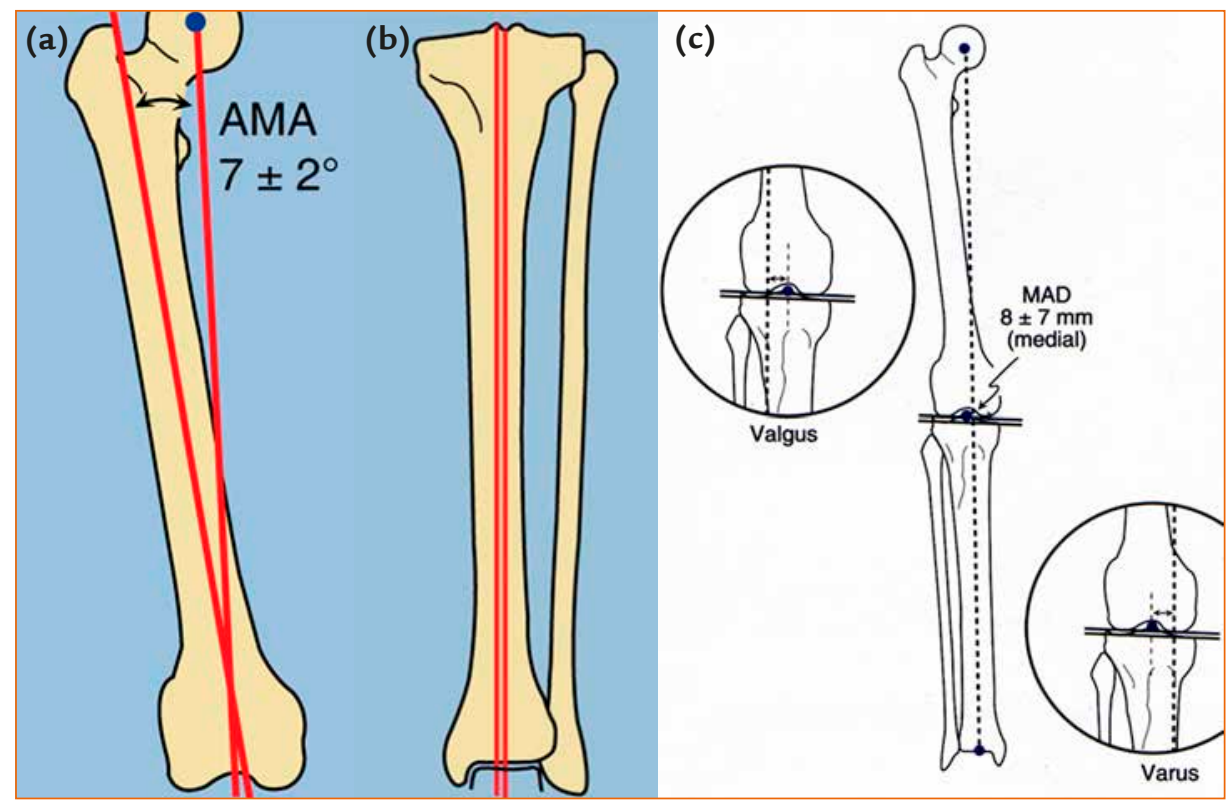

Şekil 5. a-c. Femurda mekanik aks ve anatomik aks arasında $7^{\circ}$ 'lik bir açı mevcut iken (a), tibiada mekanik aks ve anatomik aks birbirine paraleldir (b). Alt ekstremitenin normal mekanik aks deviasyonu, varus ve valgus deformiteleri (c).

mekanik eksenler gösterilmiştir. Mekanik eksen hem frontal hem sagittal planda düz bir çizgidir.

Anatomik eksen: Bir uzun kemik diafizinin orta noktalarını birleştiren çizgidir. Frontal (Şekil 4a) ve sagittal planda (Şekil 4b), femurda (Şekil 4c, 4d) ve tibiada (Şekil 4e) anatomik eksenler gösterilmiştir. Anatomik eksen her zaman düz bir çizgi değildir (Şekil 4c, femur sagittal plan).
Femurda mekanik eksen ve anatomik eksen arasında (Anatomic-Mechanic Angle)-(AMA) $7^{\circ}$ fark varken (Şekil $5 \mathrm{a}$ ), tibiada her iki eksen birbirine paraleldir (Şekil 5b) ve aynı çizgi olarak kabul edilir.

MAD = Mekanik eksen deviasyonu (mekanik eksen sapması): Alt ekstremite mekanik aksının dizin orta noktası ile arasındaki mesafeye denir. Normalde bu noktanın $8 \pm 7 \mathrm{~mm}$ medialindedir (Şekil 5c). Mekanik 


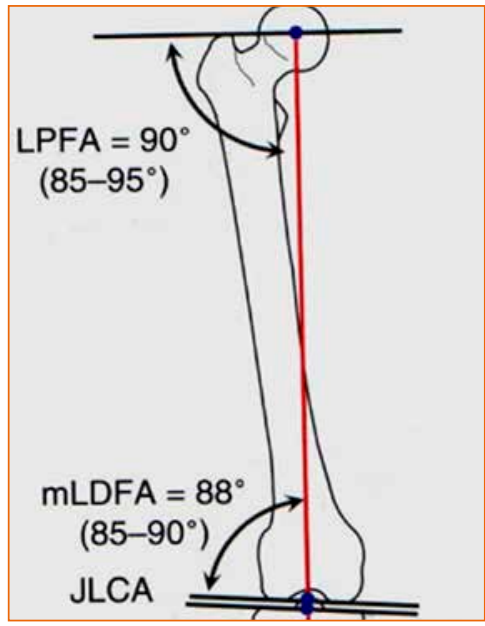

Şekil 6. Femurun mekanik aksına ait açılar (LPFA, mLDFA).

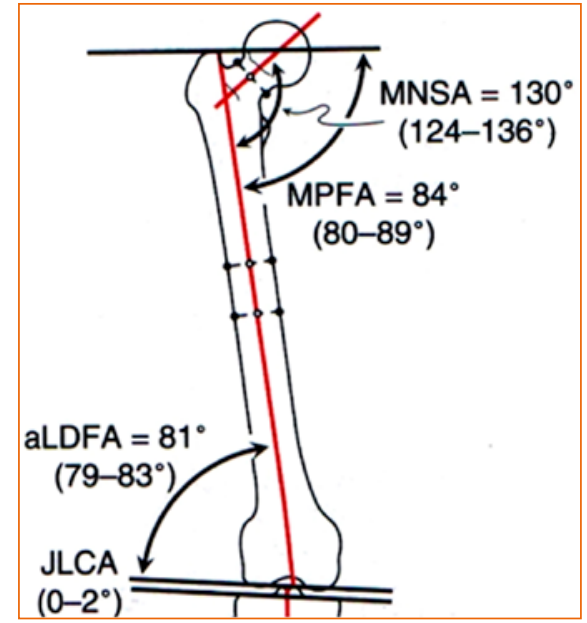

Şekil 7. Femurun anatomik aksına ait açılar (aMNSA, aMPFA, aLDFA).

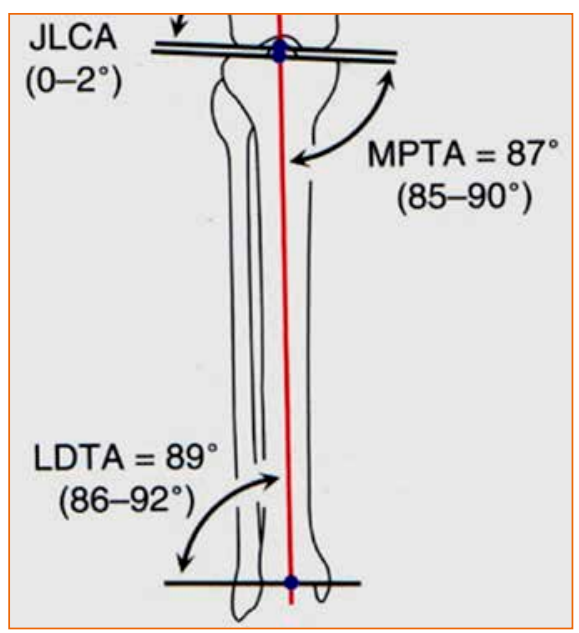

Şekil 8. Tibianın mekanik aksına ait açılar (MPTA, LDTA). eksenin normalin medialinden geçmesi 'varus' deformitesine yol açarken, mekanik aksın normalin lateralinden geçmesi 'valgus' deformitesine yol açar.

\section{Eklem Oryantasyon Çizgileri ile Mekanik ve Anatomik Eksenler Arası iliş̧kiler}

$\mathrm{Bu}$ ilişkileri göstermek için ölçülen açılar genellikle dört büyük harfle tanımlanır. Birinci harf açının yönünü tanımlar. Eğer açı frontal planda ise açı yönü ya lateral ya da medial olur. Eğer sagital planda ise ya anterior ya da posterior olur. Bu nedenle birinci harf yön kelimelerinin baş harfleri olan $L, M, A$ veya $P$ harflerinden biridir. İkinci harf açının kemiğin proksimalinde mi yoksa distalinde mi olduğunu gösterir. İkinci harf proksimalde ise $P$, distalde ise $D$ harfidir.

Üçüncü harf açının hangi kemiğe (tibia, femur) ait olduğunu gösterir. Üçüncü harf eğer açı tibia ya ait ise $T$, femura ait ise $F$ harfidir. Dördüncü harf hepsinde aynıdır ve açı kelimesinin baş harfi olan A'dır. Bunlardan farklı olarak, dört büyük harflik açı tanımı önüne küçük harfle "a" veya "m" yazılabilir; "a" harfi açının anatomik eksene göre çizildiğini, " $m$ " harfi ise mekanik eksene göre çizildiğini gösterir. ${ }^{[4,5]}$

1. mLPFA: Femur başı merkezi ile trokanter tepesini birleştiren çizgi, femur mekanik ekseni ile lateralde ortalama $90^{\circ}$ (en az $85^{\circ}$, en çok $95^{\circ}$ ) açı yapar. Bu açıya mekanik Lateral Proksimal Femoral Açı (mLPFA) (Şekil 6) adı verilir.

2. aMPFA: Femur başı merkezi ile trokanter tepesini birleştiren bu çizgi anatomik eksenle medialde ortalama $84^{\circ}$ (en az $80^{\circ}$, en çok $89^{\circ}$ ) açı yapar. Bu açıya anatomik Medial Proksimal Femoral açıya (aMPFA) adı verilir (Şekil 7).

3. aMNSA: Femur başı merkezini femur boynu orta noktası ile birleştiren çizgi anatomik eksenle medialde ortalama $130^{\circ}$ (en az $124^{\circ}$, en çok $136^{\circ}$ ) açı yapar. $\mathrm{Bu}$ açıya anatomik Medial Neck-Shaft Angle (Medial Boyun Şaft Açısı) (aMNSA) adı verilir (Şekil 7).

4. mLDFA ve aLDFA: Distal femur eklem oryantasyon çizgisi femur mekanik ekseni ile lateralde ortalama $87^{\circ}$ (en az $85^{\circ}$, en çok $90^{\circ}$ ) açı yapar (Şekil 7). Bu açıya mekanik Lateral Distal Femoral Açı (mLDFA) adı verilir. Bu çizgi anatomik eksenle lateralde ortalama $81^{\circ}$ (en az $79^{\circ}$, en çok $83^{\circ}$ ) açı yapar (Şekil 8). Bu açıya anatomik Lateral Distal Femoral Açı (aLDFA) adı verilir.

5. mMPTA: Proksimal tibia eklem oryantasyon çizgisi tibia mekanik ekseni ile medialde ortalama $87^{\circ}$ (en az $85^{\circ}$, en çok $90^{\circ}$ ) açı yapar (Şekil 8). Bu açıya mekanik Medial Proksimal Tibial Açı (mMPTA) adı verilir. Bu çizgi anatomik eksenle medialde aynı derece açı yapar. Çünkü tibianın anatomik ve mekanik ekseni aynı kabul edilir.

6. mLDTA: Distal tibia eklem oryantasyon çizgisi tibia anatomik ve mekanik ekseni ile lateralde ortalama $89^{\circ}$ (en az $86^{\circ}$, en çok $92^{\circ}$ ) açı yapar (Şekil 8). Bu açıya mekanik Lateral Distal Tibial Açı (mLDTA) adı verilir.

Alt ekstremitedeki üç büyük eklem olan kalça, diz ve ayak bileğinin her birinin sagittal planda hareket 


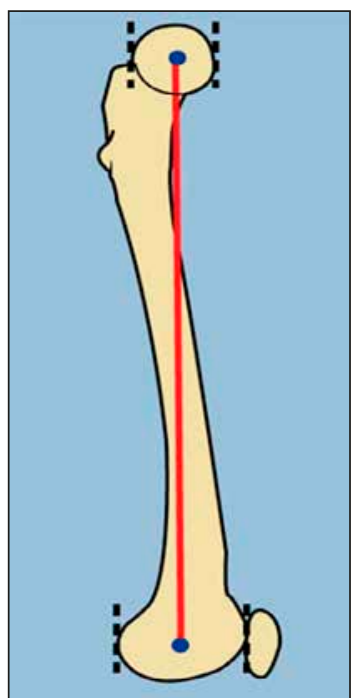

Şekil 9. Femurun sagittal planda mekanik aksı.

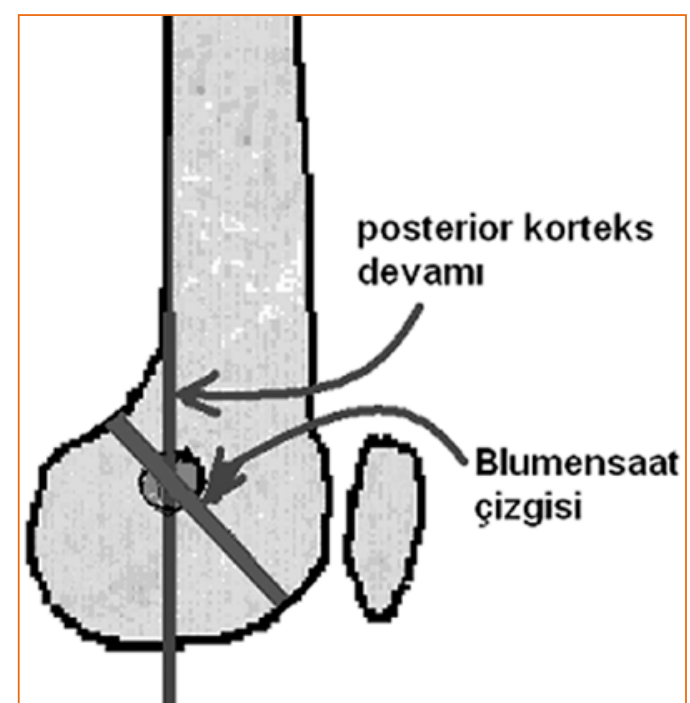

Şekil 10. Femur rotasyon merkezi. açıklıklarının geniş olması frontal plandaki deformitelere nispetle, sagittal planda kötü dizilimi daha fazla telafi eder. Özellikle rekurvatum deformiteleri prokurvatum deformitelerine göre daha iyi telafi edilir. Mevcut deformitelerin analizini yapabilmek için sagittal planda anatomik ve mekanik eksenleri çizmek, normal açıları bilmek ve sagittal plandaki problemlerde yumuşak doku komponentinin daha fazla etkisi olduğunu akılda tutmak gerekir.

Sagittal planda femur mekanik eksenini çizmek için, kalça ve diz rotasyon merkezini bulmak gereklidir (Şekil 9). ${ }^{[1]}$

Kalça rotasyon merkezi: Lateral radyografide femur başının merkezidir. Bu merkez frontal planda anlatıldığı gibi bulunur (Şekil 9). Diz rotasyon merkezi: Lateral radyografide femur posterior korteksini devam ettiren çizginin, Blumensaat çizgisiyle kesiştiği noktadır (Şekil $10)$. Kalça ve diz rotasyon merkezleri birleştirilir ve femur mekanik ekseni çizilir (Şekil 9).

Kalça rotasyon merkezi (Femur başı merkezi) ile ayak bileği rotasyon merkezini birleştiren çizgi sagital planda alt ekstremitenin mekanik eksenidir. ${ }^{[4,5]}$ Ayak bileği rotasyon merkezi olarak talusun lateral prosesi kabul edilir. Diz tam ekstansiyonda iken, sagital mekanik eksen diz ekleminin rotasyon merkezinin anteriorundan geçer. Bu durum dizin tam ekstansiyonda kilitlenebilmesini sağlar. Normal şartlarda, femoral kondillerin sagittal genişliklerinin orta noktası, tibial platoların sagittal genişliklerinin orta noktası ile aynı hizadadır. Tibianın sagittal orta noktasının femurun

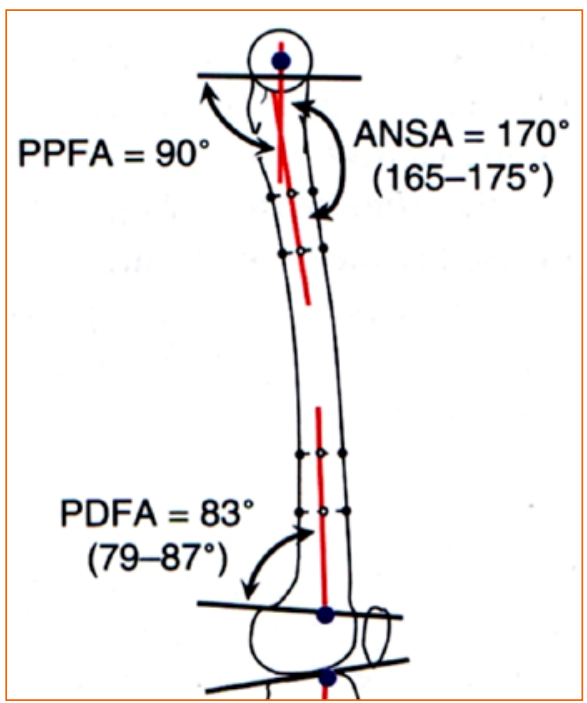

Şekil 11. Femurun sagittal planda anatomik aksına ait açılar (PPFA, ANSA, PDFA).

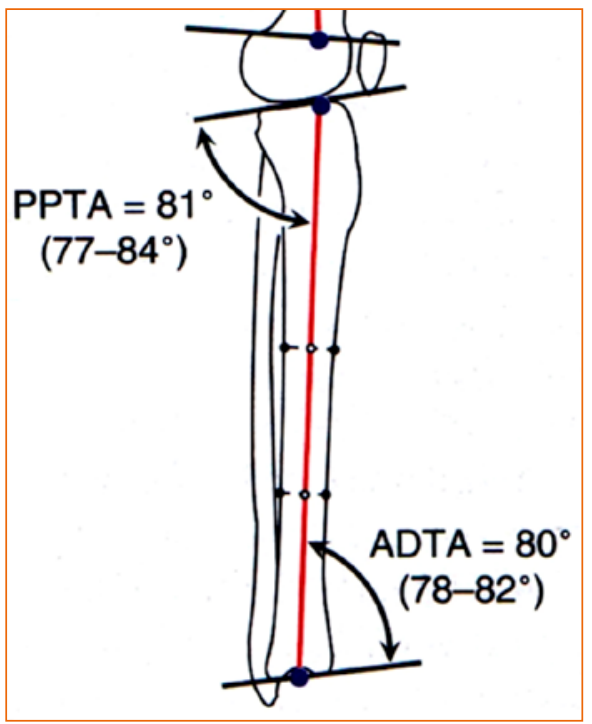

Şekil 12. Tibianın sagittal planda anatomik aksına ait açılar (PPTA, ADTA).

sagittal orta noktasına göre öne yer değiştirmesi anterior, arkaya yer değiştirmesi posterior subluksasyon olarak tanımlanır.

\section{Sagittal Planda Oryantasyon Hatları ile Anatomik ve Mekanik Eksenler Arasındaki ilişki'ye baktığımızda;}

Kalça eklem oryantasyonunu gösteren açının 'Anterior Neck-Shaft Angle' (ANSA) olduğunu ve ortalama $170^{\circ}$ açı yaptığını görüyoruz $\left(165-175^{\circ}\right.$ ) (Şekil $11)$. Diz eklem oryantasyonunu gösteren açılar ise aPDFA ve aPPTA olup (Şekil 11, 12); 
aPDFA açısı: Distal femur oryantasyon hattı, femur anatomik ekseni ile posteriorda ortalama $83^{\circ}$ lik (en az $79^{\circ}$, en çok $87^{\circ}$ ) bir açı yapar. Bu açıya anatomik Posterior Distal Femoral Açı (aPDFA) adı verilir (Şekil 11). Femur anatomik ekseni distal femur oryantasyon hattını 2/3 anteriorda keser.

aPPTA açısı: Sagittal orta diafizyal hattın (tibia anatomik ekseni) proksimal tibia eklem oryantasyon hattını kesmesi ile (bu nokta genellikle eklem hattının 1/5 anteriorunda yer alır) oluşan açıdır (Şekil 12). Bu açıya anatomik Posterior Proksimal Tibial Açı (aPPTA) adı verilir. Ortalama $81^{\circ}$ dir (en az $77^{\circ}$, en çok $84^{\circ} \mathrm{e}$ ).

Ayak bileği oryantasyonunu gösteren açı ise aADTA'dır.

aADTA: Distal tibia eklem oryantasyon hattı, tibia anatomik ekseni ile ortalama $80^{\circ}$ 'lik (en az $78^{\circ}$, en çok $82^{\circ}$ ) bir açı yapar. Bu açıya anatomik Anterior Distal Tibial Açı (aADTA) adı verilir (Şekil 12).

Yukarıda detaylandırımış açılar deformite analizi için evrensel açılar olup, son olarak evrensel prensipler kısaca özetlenecektir.

Frontal plan deformite analizi prensiplerine bakıldığında;

1- Alt ekstremitenin mekanik ekseni çizilir

2- Mekanik eksens deviasyonu (sapması) ölçülür

3- Femurun mekanik ekseni çizilir

4- Tibianın mekanik ekseni çizilir

5- Eklem oryantasyon çizgileri çizilir

6- Oryantasyon açıları ölçülür: mLDFA, mMPTA, mLDTA, mLPFA.
Sagittal Plan'da yapılacak deformite analizi prensipleri de frontal plan analizi ile aynı sıralama ile yapılır;

1- Alt ekstremitenin mekanik ekseni çizilir

2- Anterior kortikal çizgiler çizilir

3- Femurun modifiye mekanik ekseni çizilir (distal'de $1 / 3$ anteriordan geçer)

4- Tibianın modifiye mekanik ekseni çizilir

(proksimalde 1/5 anterior, distalde 1/2 anteriordan geçer)

5- Eklem oryantasyon çizgileri çizilir

6- Oryantasyon açıları ölçülür: aPDFA, aPPTA, aADTA

\section{KAYNAKLAR}

1. Çakmak M, Bilen FE. Menteşe tipleri ve yerleştirilmesi. İçinde: Çakmak M, Kocaoğlu $M$, editörler. İlizarov Cerrahisi ve Prensipleri. İstanbul; 1999. ss.63-78.

2. Gülşen M. Deformite düzeltilmesi prensipleri. İçinde: Çakmak M, Kocaoğlu M, editörler. İlizarov Cerrahisi ve Prensipleri. İstanbul; 1999. ss.145-66.

3. Kocaoğlu M. Frontal ve sagittal plandaki deformitelerin Illizarov yöntemi ile tedavisi, 1. Ileri Illizarov Kursu Ders Notları, Adana. Çukurova Tıp Fakültesi, Ortopedi ve Travmatoloji Anabilim Dalı, Vol:1. 1997. ss.12-30.

4. Paley D. Frontal Plane Mechanical and Anatomic Axis Planning. In: Paley D. Principles of Deformity Correction, Berlin: Springer-Verlag; 2002. ss.61-97.

5. Paley D. Sagittal Plane Deformities. In: Paley D. Principles of Deformity Correction, Berlin: Springer-Verlag; 2002. ss.155-74. 